\title{
Trichotomol, a New Cadinenediol from Cordia trichotoma
}

\author{
Jane Eire S. A. Menezes ${ }^{a}$, Telma L. G. Lemos ${ }^{a}$, Edilberto R. Silveira ${ }^{a}$, \\ Raimundo Braz-Filho ${ }^{b}$ and Otília Deusdênia L. Pessoa ${ }^{a^{*}}$ \\ ${ }^{a}$ Departamento de Química Orgânica e Inorgânica, Universidade Federal do Ceará, \\ CP 12.200, 60455-970, Fortaleza-CE, Brazil \\ ${ }^{b}$ Setor de Química de Produtos Naturais - LCQUI - CCT, Universidade Estadual do \\ Norte Fluminense, 28015-620, Campos - RJ, Brazil
}

\begin{abstract}
Um novo sesquiterpeno, nomeado trichotomol e compostos conhecidos como cordiacromo $\mathrm{C}$, $\alpha$-cadinol, ácido oleanólico, oncocalyxona A, $\beta$-sitosterol, glicosídeo do $\beta$-sitosterol, alantoína e sacarose foram isolados a partir do extrato etanólico do cerne de Cordia trichotoma. Suas estruturas foram determinadas por análises espectroscópicas e comparação com dados publicados para compostos estruturalmente relacionados.
\end{abstract}

A new sesquiterpene, named trichotomol, and known compounds cordiachrome $\mathrm{C}$, $\alpha$-cadinol, oleanolic acid, oncocalyxone A, $\beta$-sitosterol, $\beta$-sitosterol- $\beta$-D-glucoside, allantoin and sucrose were isolated from the heart wood ethanol extract of Cordia trichotoma. Their structures were assigned unambiguously by spectroscopic analyses and comparison with the published data for structurally related compounds.

Keywords: Cordia trichotoma, Boraginaceae, sesquiterpene, trichotomol, cordiachrome C

\section{Introduction}

Cordia trichotoma Vell. (Boraginaceae) is a tropical tree, popularly known as "frei jorge"1. According to a literature survey, several uses in traditional medicine such as cicatrizant, astringent, anti-inflammatory, antihelminthic, antimalarial, diuretic and to treat urinary infections, lung diseases and leprosy have been reported for several Cordia species $^{2-4}$. No medicinal use has been reported for C. trichotoma, but its wood is recognized for its durability in carpentry and construction ${ }^{1}$. Previous phytochemical investigations of plants from this genus have described several natural products structurally related to terpenoid quinone and hydroquino-nes ${ }^{5-}$ 7. In the last few years, several articles have been published on this kind of compounds, from Auxemma genus ${ }^{8-10}$, belonging to the same family and formerly considered synonimous of Cordia. To the best of our knowledge, except for a publication in which the presence of eudesmol isomers from $C$. trichotoma wood ${ }^{11}$ has been recorded, there have been no other reports of any similar chemical investigation in the literature. In this paper we describe the isolation and structure elucidation of the known compounds: $\beta$-sitosterol,

e-mail: otilia@dqoi.ufc.br sitosterol- $\beta$-D-glucoside ${ }^{12}$, oleanolic acid $^{13}$, allantoin ${ }^{14}$, sucrose ${ }^{15}, \alpha$-cadinol ${ }^{16}$, oncocalyxone $\mathrm{A}^{8}$, cordiachrome $\mathrm{C}^{5}$, and a new sesquiterpene, trichotomol (1). Although cordiachrome $\mathrm{C}(\mathbf{2})$ had been previously isolated from $C$. millenii, only the partial ${ }^{1} \mathrm{H}$ NMR data was provided but some doubt about its stereochemistry ${ }^{5}$ has remained. Here the complete ${ }^{1} \mathrm{H}$ and ${ }^{13} \mathrm{C}$ spectral data and assignments for $\mathbf{2}$ are reported for the first time and used to corroborate the stereochemical aspects.

\section{Results and Discussion}

Compound 1 was obtained as colorless crystals, $\mathrm{mp}$ $159-160{ }^{\circ} \mathrm{C}$ and $[\alpha]_{589}=-17.1\left(c 0.7, \mathrm{CHCl}_{3}, 23^{\circ} \mathrm{C}\right)$. Its IR spectrum revealed hydroxyl $\left(3353 \mathrm{~cm}^{-1}\right.$ and $\left.1116 \mathrm{~cm}^{-1}\right)$ and olefinic $\left(1657 \mathrm{~cm}^{-1}\right)$ absorptions.

The molecular formula $\mathrm{C}_{15} \mathrm{H}_{26} \mathrm{O}_{2}$, which indicates three double-bond equivalents, was deduced using EIMS, ${ }^{13} \mathrm{C}$ NMR, and DEPT analyses. The ${ }^{13} \mathrm{C}$ NMR (BB and DEPT) spectra displayed signals corresponding to four methyl, four methylene, four methine, and three nonhydrogenated carbons. Resonances due to two olefinic carbons at $\delta_{\mathrm{C}} 134.3(\mathrm{C})$ and $124.7(\mathrm{CH})$ in the ${ }^{13} \mathrm{C} \mathrm{NMR}$ spectrum accounted for one double-bond equivalent, 
suggesting that $\mathbf{1}$ as a bicyclic compound. Two of the nonhydrogenated saturated carbons, $\delta_{\mathrm{C}} 74.2$ and 72.1 , were shifted to high frequency indicating they were attached to oxygen atoms. The EIMS spectrum did not present the molecular ion, but showed ions at $m / z 220\left(\mathrm{M}-\mathrm{H}_{2} \mathrm{O}\right)$ and $202\left(\mathrm{M}-2 \mathrm{H}_{2} \mathrm{O}\right)$, in agreement with the presence of two hydroxyl groups for $\mathbf{1}$. The ${ }^{1} \mathrm{H}$ NMR spectrum indicated resonances corresponding to four methyl groups, three of which were attached to carbons bearing hydroxyl groups: $\delta_{\mathrm{H}}$ $1.09(\mathrm{~s}), 1.19(\mathrm{~s})$ and $1.20(\mathrm{~s})$, while the third one $\left(\delta_{\mathrm{H}} 1.64, \mathrm{~s}\right)$ due to the high frequency chemical shift seemed to be attached to a double bond. The presence of just one olefinic hydrogen $\delta_{\mathrm{H}} 6.14$ (br s), suggested the presence of a trisubstituted double bond which is in accordance with ${ }^{13} \mathrm{C}$ NMR data.

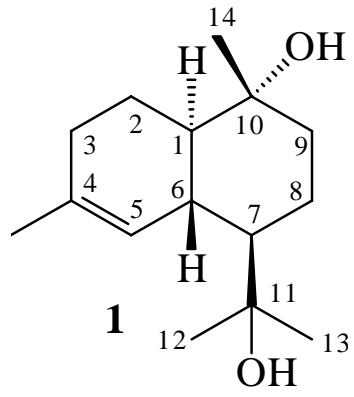

These data were similar to those reported for $\alpha$-cadinol ${ }^{16}$. Except for the observed differences, especially for the carbon atoms at $\delta_{\mathrm{C}} 53.0(\mathrm{C}-7), 74.2(\mathrm{C}-11), 24.1$ (C-12) and 32.1 (C-13), of $\mathbf{1}$ in respect to those of $\alpha$-cadinol, what could be explained by the existence of an additional $\mathrm{C}-11$ hydroxyl group in $\mathbf{1}$. The slight difference between the chemical shift of methyls $\mathrm{C}-12$ and $\mathrm{C}-13$ ( $\delta_{\mathrm{C}} 24.1$ and 32.1 , respectively) revealed that there is no free rotation around the single bond $\mathrm{C}_{7}-\mathrm{C}_{11}$, as expected. From the NOESY data it was possible to assign unambiguously the chemical shift of both carbons through the dipolar interaction of $\mathrm{H}-6\left(\delta_{\mathrm{H}} 1.93\right)$ with the slightly more protected $\mathrm{H}-12\left(\delta_{\mathrm{H}} 1.19\right)$ and the equatorial $\mathrm{H}-8\left(\delta_{\mathrm{H}}\right.$ $1.75)$ with the other one $\mathrm{H}-13\left(\delta_{\mathrm{H}} 1.20\right)$. HMQC data it was easy to assign both carbon chemical shifts.

The relative stereochemistry of $\mathbf{1}$ was determined by analysis of the NOESY spectrum. The observed nOes for $\mathrm{H}-1 \alpha, \mathrm{H}-2 \alpha, \mathrm{H}-9 \alpha$ and $\mathrm{H}-7 \alpha$; for $\mathrm{H}-6 \beta, \mathrm{H}-2 \beta$ and $3 \mathrm{H}-14 \beta$ were consistent with a trans configuration of the $\mathrm{A} / \mathrm{B}$ rings. These data also suggested that the configurations of HO10 and $\mathrm{HO}\left(\mathrm{CH}_{3}\right)_{2} \mathrm{C}-7$ groups were $\alpha$ and $\beta$, respectively (Figure 1). Based on these data, the structure of $\mathbf{1}$ was determined as the $10 \alpha, 11$-dihydroxy-4-cadinene, which is a new sesquiterpene.

Compound 2 was obtained as an orange oil, and its molecular formula, $\mathrm{C}_{16} \mathrm{H}_{18} \mathrm{O}_{2}$, was suggested by ${ }^{13} \mathrm{C}$ NMR,

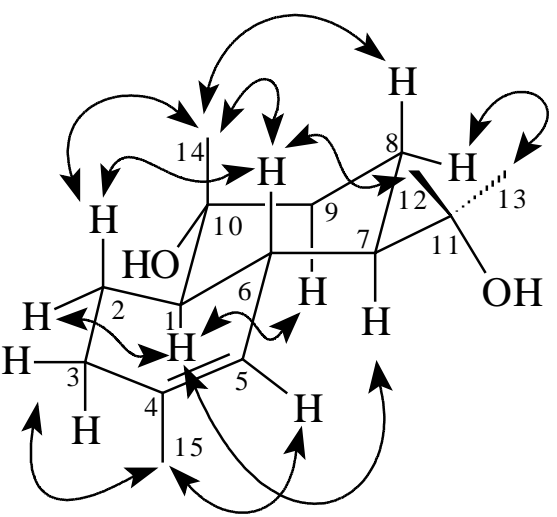

Figure 1. ${ }^{1} \mathrm{H}-{ }^{1} \mathrm{H}$ dipolar correlations of $\mathbf{1}$ observed through NOESY experiment.

DEPT, and EIMS $\left(\mathrm{m} / \mathrm{z} 242,[\mathrm{M}]^{+}\right)$. The IR spectrum of $\mathbf{2}$ showed the presence of carbonyl $\left(1680 \mathrm{~cm}^{-1}\right)$ and olefinic $\left(1656 \mathrm{~cm}^{-1}\right)$ groups.

Comparative analysis of $\mathrm{BB}$ and DEPT $-{ }^{13} \mathrm{C}$ NMR spectra revealed six $\mathrm{sp}^{3}$ carbons (two methyls, two methylenes, one methine and one quaternary), two carbonyl groups and eight $\mathrm{sp}^{2}$ carbons (three non-hydrogenated, three methines and two methylenes). The presence of a 1,4benzoquinone moiety was revealed by the chemical shifts for $\mathrm{H}-2 \delta_{\mathrm{H}}(6.70, \mathrm{~d}, J 9.2 \mathrm{~Hz})$ and $\mathrm{H}-3 \delta_{\mathrm{H}}(6.68, \mathrm{~d}, J 9.2 \mathrm{~Hz})$, and for the carbons atoms $\mathrm{C}-1\left(\delta_{\mathrm{C}} 187.1\right)$ and $\mathrm{C}-4\left(\delta_{\mathrm{C}} 186.9\right)$.

The $500 \mathrm{MHz}{ }^{1} \mathrm{H}$ NMR spectrum presented information for all signals, including the homoallylic coupling of the methylene groups $2 \mathrm{H}-5\left[\delta_{\mathrm{H}} 2.66(\mathrm{H}-5 \alpha), 2.24(\mathrm{H}-5 \beta)\right]$, and $2 \mathrm{H}-8\left[\delta_{\mathrm{H}} 2.60(\mathrm{H}-8 \beta), 2.44(\mathrm{H}-8 \alpha)\right]$. The signal at $\delta_{\mathrm{H}}$ $2.18(\mathrm{dd}, J 11.1$ and $5.0 \mathrm{~Hz}$ ) was attributed to $\mathrm{H}-10 \mathrm{a}$, whose coupling constant values correspond to vicinal spin-spin interaction between hydrogens $\mathrm{H}-10$ and $\mathrm{H}-10 \mathrm{a}$.

${ }^{1} \mathrm{H}$ - and ${ }^{13} \mathrm{C}$-NMR spectra (DEPT and HMQC) also showed signals related to the methylene of a vinyl group $\mathrm{CH}=\mathrm{CH}_{2} \delta_{\mathrm{H}}[5.87(\mathrm{dd}, J 10.9$ and $17.5 \mathrm{~Hz}, \mathrm{H}-14), 4.98$ (d, $J 10.9 \mathrm{~Hz}, \mathrm{H}-15 \mathrm{a}), 4.87$ (d, $J 17.7 \mathrm{~Hz}, \mathrm{H}-15 \mathrm{~b})]$ and the methylene of an isopropenyl group $-\mathrm{C}\left(\mathrm{CH}_{3}\right)=\mathrm{CH}_{2} \delta_{\mathrm{H}}[4.88$ (s, H-12a), 4.74 (s, H-12b), 1.73 (s, 3H-13)]. The heteronuclear long-range interaction between the methyl carbon $\mathrm{CH}_{3}-13\left[\delta_{\mathrm{C}} 23.2 ; \delta_{\mathrm{H}} 1.73(\mathrm{~s})\right]$ and hydrogens $2 \mathrm{H}-12$ $\delta_{\mathrm{H}}[4.88(\mathrm{~s})$ and $4.74(\mathrm{~s})]$ and $\mathrm{H}-7\left(\delta_{\mathrm{H}} 2.18\right.$, dd, $J 11.1$ and $5.0 \mathrm{~Hz}$ ) observed in the HMBC spectrum, was also used to locate that methyl at carbon $\mathrm{C}-5\left(\delta_{\mathrm{C}} 145.1\right)$.

The cis relative configuration for the double bond moieties was supported from the chemical shift at $\delta 1.11$ corresponding to the angular methyl $\left(\mathrm{CH}_{3}-16\right)^{5}$. The proposed stereochemistry was also supported by the NOESY experiment (Figure 2), that showed correlation between $\mathrm{H}-5 \beta, 3 \mathrm{H}-16$ and $\mathrm{H}-7$. Thus, 2 was identified as 6-ethenyl-5,6,7,8-tetrahydro-6-methyl-7-(1-methylethenyl)-1,4-naphthalenedione. 


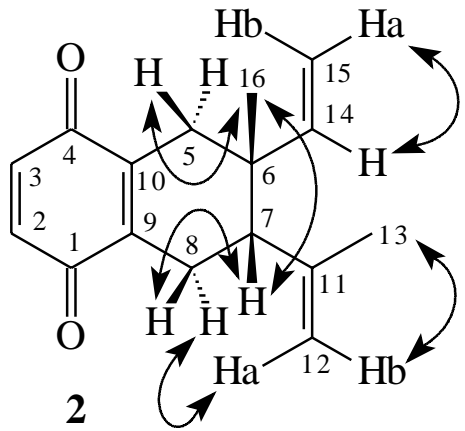

Figure 2. ${ }^{1} \mathrm{H}-{ }^{1} \mathrm{H}$ dipolar correlations of 2 observed through NOESY experiments.

\section{Experimental}

\section{General experimental procedures}

Melting points were determined using a melting point apparatus and are uncorrected. IR spectra were obtained on a Perkin-Elmer 1000 FT-IR instrument. EIMS data were obtained using a VG-Auto Spec mass spectrometer. Optical rotations were measured in a Perkin-Elmer 341 digital polarimeter. The NMR spectra were recorded in a Bruker DRX $500\left[500 \mathrm{MHz}\left({ }^{1} \mathrm{H}\right)\right.$ and $\left.125 \mathrm{MHz}\left({ }^{13} \mathrm{C}\right)\right]$ spectrometer. Chemical shifts were recorded in $\delta$ (ppm) from TMS relative to the solvent absorption relative to TMS, $\mathrm{CDCl}_{3} \delta(7.24$ and $77.0 \mathrm{ppm}$ ), and DMSO- $d_{6}$ (2.49 and $39.5 \mathrm{ppm}$ ). Column chromatography (CC) was performed using silica gel 60 (Merck). TLC analysis were performed on precoated silica gel $\mathrm{UV}_{254}$ plates (Aldrich). Visualization of TLC plates was performed using a mixture of vanillin-perchloric acid-EtOH as a spray reagent. Spots were visualized by spraying the plates and then heating them at $100{ }^{\circ} \mathrm{C}$ for $1-3 \mathrm{~min}$ in a oven.

\section{Plant material}

Cordia trichotoma was collected in March 1998, at the Meruoca mountain, State of Ceará, Brazil, and identified by A. S. Nogueira de Castro and E. P. Nunes, botanists of the Universidade Federal do Ceará, where a voucher specimen is deposited (Herbarium Prisco Bezerra, No. 25.165).

\section{Extraction and Isolation}

The air-dried and pulverized heartwood $(2.0 \mathrm{~kg})$ was exhaustively extracted with EtOH at room temperature and then concentrated under vacuum to yield $124.0 \mathrm{~g}$ of a brown residue. The ethanol extract was first fractioned by $\mathrm{CC}$ with hexane, $\mathrm{CHCl}_{3}$, EtOAc and $\mathrm{MeOH}$. The hexane fraction was subjected to $\mathrm{CC}$ and eluted with mixtures of hexane and EtOAc of increasing polarities to give $\beta$-sitosterol (176.0 mg, mp 162-164 ${ }^{\circ} \mathrm{C}$ ), oleanolic acid (25.0 mg, mp $\left.>300{ }^{\circ} \mathrm{C}\right), \alpha$-cadinol $\left(58.0 \mathrm{mg}, \mathrm{mp} 73-74{ }^{\circ} \mathrm{C}\right)$ and the new compound 1 (186.0 mg, mp 158-160 ${ }^{\circ} \mathrm{C}$ ). Similarly, CC of the $\mathrm{CHCl}_{3}$ fraction, eluting with an hexane-EtOAc gradient, yielded oncocalyxone A (73.0 mg, mp 208-209 $\left.{ }^{\circ} \mathrm{C}\right)$ and cordiachrome $\mathrm{C}(2,32.6 \mathrm{mg})$. The EtOAc fraction gave $\beta$ sitosterol- $\beta$-D-glucoside $\left(287.0 \mathrm{mg}\right.$, $\left.\mathrm{mp} 289-292^{\circ} \mathrm{C}\right)$, after repeated $\mathrm{CC}$, using EtOAc-MeOH as eluent. From the $\mathrm{MeOH}$ fraction a precipitate was collected and was identified as sucrose $\left(2.96 \mathrm{~g}, \mathrm{mp} 185-186^{\circ} \mathrm{C}\right)$. The residue from the supernanant $\mathrm{MeOH}$ fraction, after evaporation, was submitted to $\mathrm{CC}$. Elution with increasing polarity with $\mathrm{CHCl}_{3}$ /EtOAc gave allantoin (630.0 mg, $\left.\mathrm{mp} 230-232^{\circ} \mathrm{C}\right)$.

Compound 1. $\mathrm{C}_{15} \mathrm{H}_{26} \mathrm{O}_{2}$, 10 $\alpha$,11-dihydroxy-4-cadinene. (185.6 mg, 1,49\%); colorless crystal, mp $159-160{ }^{\circ} \mathrm{C}$ $\left(\mathrm{CHCl}_{3}\right) ;[\alpha]_{589}=-17.1\left(c 0.7, \mathrm{CHCl}_{3}, 23^{\circ} \mathrm{C}\right) ; \mathrm{IR} v_{\text {max. }}$ ! $\mathrm{cm}^{-1}$ 3353, 2961, 2863, 1657, 1457, 1375, $1116(\mathrm{KBr}) ;{ }^{1} \mathrm{H}$ $\mathrm{NMR}\left(\mathrm{CDCl}_{3}, 500 \mathrm{MHz}\right) \delta 1.26(\mathrm{~m}, \mathrm{H}-1), 1.99(\mathrm{~m}, \mathrm{H}-2 \alpha)$,

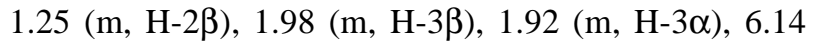
(s, H-5), 1.93 (m, H-6), 1.21 (m, H-7), 1.75 (m, H-8a), 1.03 (m, H-8ß), 1.46 (dq, $J 3.4$ and $12.5 \mathrm{~Hz}, \mathrm{H}-9 \alpha$ ), 1.78 (dq, $J$ 3.4 and $12.5 \mathrm{~Hz}, \mathrm{H}-9 \beta), 1.19$ (s, 3H-12), 1.20 (s, 3H-13), 1.09 (s, 3H-14), 1.64 (s, 3H-15); ${ }^{1} \mathrm{H}$ NMR (DMSO- $d_{6}, 500$ $\mathrm{MHz}) \delta 4.04$ (s, HO-10), 4.11 (s, HO-11); ${ }^{13} \mathrm{C} \mathrm{NMR}\left(\mathrm{CDCl}_{3}\right.$, $125 \mathrm{MHz}$,) $\delta 49.8(\mathrm{CH}-1), 22.7\left(\mathrm{CH}_{2}-2\right), 30.6\left(\mathrm{CH}_{2}-3\right)$, 134.3 (C-4), 124.7 (CH-5), 40.8 (CH-6), 53.0 (CH-7), 27.1 $\left(\mathrm{CH}_{2}-8\right), 42.3\left(\mathrm{CH}_{2}-9\right), 72.1$ (C-10), 74.2 (C-11), 24.1 $\left(\mathrm{CH}_{3}-12\right), 32.1\left(\mathrm{CH}_{3}-13\right), 20.7\left(\mathrm{CH}_{3}-14\right), 24.1\left(\mathrm{CH}_{3}-15\right)$; EIMS $(70 \mathrm{eV}) \mathrm{m} / \mathrm{z} 220\left(\mathrm{M}-\mathrm{H}_{2} \mathrm{O}, 5\right), 202\left(\mathrm{M}-2 \mathrm{H}_{2} \mathrm{O}, 47\right)$, 43 (100).

Compound 2. $\mathrm{C}_{16} \mathrm{H}_{18} \mathrm{O}_{2}$, 6-ethenyl-5,6,7,8-tetrahydro6-methyl-7-(1-methylethenyl)-1,4-naphthalenedione. (32.6 $\mathrm{mg}, 0,026 \%)$; orange oil; $[\alpha]_{589}=-1.11\left(c 0.27, \mathrm{CHCl}_{3}, 23\right.$ $\left.{ }^{\circ} \mathrm{C}\right)$; IR $v_{\text {max. }} / \mathrm{cm}^{-1} 2920,2851,1680,1656,1464,1376$, 1278, 908, 725 (film); ${ }^{1} \mathrm{H} \mathrm{NMR}\left(\mathrm{CDCl}_{3}, 500 \mathrm{MHz}\right) \delta 6.69$ (d, J 9.2 Hz, H-2), 6.67 (d, J 9.2 Hz, H-3), 2.66 (d, J 19.4

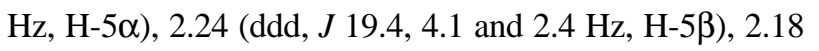
(dd, $J 11.1$ and $5.0 \mathrm{~Hz}, \mathrm{H}-7$ ), 2.60 (dd, $J 19.9$ and $2.6 \mathrm{~Hz}, \mathrm{H}-$ $8 \beta$ ), 2.44 (dddd, $J$ 19.9, 11.1, 4.1 and $2.0 \mathrm{~Hz}, \mathrm{H}-8 \alpha$ ), 4.89 (s, H-12a), 4.74 (s, H-12b), 1.73 (s, Me-13), 5.87 (dd, J 17.5, and $10.9 \mathrm{~Hz}, \mathrm{H}-14), 4.98$ (d, $J 10.9 \mathrm{~Hz}, \mathrm{H}-15 \mathrm{a}), 4.87$ (d, $J$ $17.5 \mathrm{~Hz}, \mathrm{H}-15 \mathrm{~b}), 1.11$ (s, Me-16); ${ }^{13} \mathrm{C} \mathrm{NMR}\left(\mathrm{CDCl}_{3}, 125\right.$ MHz) $\delta 186.9$ (C-1), 136.3 (CH-2), 136.3 (CH-3), 187.1 (C-4), $36.2\left(\mathrm{CH}_{2}-5\right), 37.7$ (C-6), $49.4(\mathrm{CH}-7), 26.5\left(\mathrm{CH}_{2}-\right.$ 8), 141.6 (C-9), 140.7(C-10), 145.0 (C-11), $113.8\left(\mathrm{CH}_{2}-\right.$ 12), $23.1\left(\mathrm{CH}_{3}-13\right), 141.3$ (CH-14), $113.4\left(\mathrm{CH}_{2}-15\right), 26.1$ $\left(\mathrm{CH}_{3}-16\right)$; EIMS (70 eV) m/z $242\left(\mathrm{M}^{+}, 15\right), 227$ (M - $\left.\mathrm{CH}_{3}, 100\right), 199$ (19).

\section{Acknowledgments}

The authors are grateful to CNPq, CAPES, FUNCAP, and 
BNB for financial support; to A. S. Nogueira de Castro and E. P. Nunes for plant identification, to CENAUREMN/UFC for the NMR spectra and to PADETEC/UFC for the MS spectra.

\section{References}

1. Lorenzi, H. Árvores Brasileiras; Editora Plantarum Ltda; 1992, p. 74.

2. Sertié, J. A. A.; Basile, A. C.; Panizza, S.; Matida, A. K.; Zelnik, R. Planta Med. 1990, 56, 36.

3. Marston, A.; Zagorski, M. G.; Hostettmann, K. Helv. Chim. Acta 1988, 71, 1210.

4. Tiwari, R. D.; Srivastava, K. C.; Shukla, S.; Bajpai, R. K. Planta Med. 1967, 15, 144.

5. Moir, M.; Thomson, R. H.; Hauson, B. M.; Simatupang, M. H. J. Chem. Soc., Chem. Commun. 1972, 363.

6. Moir, M.; Thomson, R. H. J. Chem. Soc., Perkin Trans. I, 1973, 1352.
7. Manners, G. D.; Jurd L. J. Chem. Soc., Perkin Trans. I, 1977, 405.

8. Pessoa, O. D. L.; Lemos, T. L. G.; Silveira, E. R.; Braz-Filho, R. Nat. Prod. Lett. 1993, 2, 145.

9. Pessoa, O. D. L.; Lemos, T. L. G.; Carvalho, M. G.; Braz-Filho, R. Phytochemistry 1995, 40, 1777.

10. Costa, G. M.; Lemos, T. L. G.; Pessoa, O. D. L.; Monte, F. J. Q.; Braz-Filho, R. J. Nat. Prod. 1999, 62, 1044.

11. Seikel, M. K.; Rowe, J. W. Phytochemistry 1964, 3, 27.

12. Macari, P. A. T.; Emerenciano, V. P.; Ferreira, Z. M. G. S. Quim. Nova 1990, 13, 260.

13. Pouchurt, C. J.; Behnke, J. The Aldrich Library of $C^{13}$ and $H^{1}$ NMR Spectra New York - USA, 1993.

14. Coxon, B.; Fatiadi, A. J.; Sniegosk, L. T.; Hertz, H. S.; Schaffer, R. J. Org. Chem. 1977, 42, 3132.

15. Pfeffer, P. E.; Valentine, K. M.; Parrish, F. W. J. Am. Chem. Soc. 1979, 107,1265.

16. Chalchat, J. C.; Garry, R. P.; Michet, A. Planta Med. 1985, 3, 285.

Received: July 14, 2000 Published on the web: September 13, 2001 